\title{
UM MERO MELRO AZUL
}

Wilson Filho Ribeiro de Almeida ${ }^{1}$

Quiçá o que a quem eu quero

Ceder e dar um simples melro seja:

Em forma e formosura vai um beijo mero

Nos poros da bochecha onde o seu suor goteja.

Talvez - com tino e tato itero

O dito e o dado - um melro simples seja,

Que lembre e lembrar faça aquele tempo mero,

A joia de presente que o colo seu deseja.

Pois, quando canta, a ave solitária impera

Nas escarpas: calma e bela e tão taful,

Trazendo a nossa prima Primavera.

Se acaso - indago, enfim, ao vero Vento Sul

- de mim o mimo que o seu peito espera

Seja um mero melro azul.

1 Mestrando em Teoria Literária pelo Programa de Pós-Graduação em Letras da Universidade Federal de Uberlândia (UFU). Graduado Bacharel em Artes Plásticas pela UFU. wilson-filho.blogspot.com 
Revista Crioula - nº 9 - Maio de 2011 